International Journal of Engineering \& Technology, $7(3.36)(2018) 96-100$
International Journal of Engineering \& Technology
SPC
Website: www.sciencepubco.com/index.php/IJET
Research paper

\title{
The Application and Challenges of Earned Value Management (EVM) As Cost Monitoring Tool in the Construction Industry
}

\author{
Noorhidayah Sunarti ${ }^{1 *}$ Zetty Pakir Mastan² Lum Seon Cin ${ }^{3}$ \\ ${ }^{1 *}$ Faculty of Engineering \& Quantity Surveying, INTI International University \\ ${ }^{2}$ INTI International University \\ ${ }^{3}$ INTI International University \\ *Corresponding author E-mail: noorhidayah.sunarti@newinti.edu.my
}

\begin{abstract}
Earned Value Management (EVM) is one of the fundamental approaches acting as a comprehensive project management and controlling technique for tracking the costs and examining project expenditures relative to the physical progress of work. Majority of the previous literature reviews and findings indicates the positive contributions of EVM in monitoring the project time-cost performance progressively and forecasting its future trends. However, EVM was not widely used as practically, the traditional cost and schedule monitoring tool is still very common in the construction industry. Thus, this research was conducted using quantitative method to the identified quantity surveying, project management and construction firms in Klang Valley area to achieve the objectives of; (1) to identify the implementation level of EVM in construction projects, (2) to recognize the EVM contribution as cost monitoring tool compared to the other mehods, and (3) to ascertain the challenges in using EVM. Based on the result, majority has reaffirmed that EVM is positively contribute to project cost monitoring and provide an overall effective cost management tools in their projects. Despite the major challenges identified in using EVM are due to the lack of EVM knowledge, expertise and experience by the user in the industry, the results also indicating that more construction players have come to realize that integration of cost and time management in EVM is beneficial to the construction industry.
\end{abstract}

Keywords: Earned Value Management, Cost Monitoring Tools, Construction industry, Application, Challenges

\section{Introduction}

Cost and schedule overruns is common yet critical problem in the construction industry. In [12] states that about half of the Malaysia construction industry encountered about $72.88 \%$ cost overruns. A numbers of literature reviews [2, 3, 6, 7, 8, 9, 10, and 11] support the positive contribution of EVM. Dayal [1] states that coupling with EVM problems in cost and schedule overruns can be eliminated. Besides, [10] constructed a case study in the effectiveness of applying EVM and derived a report providing exact project information and the decisions in mitigating the risks. Furthermore, [3] concluded that EVM provide clear understanding in project issue to the stakeholder and effective management decision. Apart from that, Robert [11] had also conducted research suggested that EVM implementation result in great project success and moderate effect from contract. Although majority of the findings show positive comments in EVM, still [7] argues that EVM is just an extension of traditional approach and [8] states that practically, the traditional cost and schedule monitoring tool is still very common in the industry.

\section{Literature Review}

\subsection{Definition and Concept of EVM}

Earned value was first developed by US Department of Defense (DoD) since 1960s. According to [4], earned value refers how much had contractor "earned" from amount budgeted for the work completed. This value use and compared with other cost and schedule data project status. [6] defined EVM as project management and controlling system integrating cost, schedule and the physical progress. It allows tracking from plan to actual cost and time performances and predicts future performances. The basic premise of EVM is that the value of a piece of work is equal to the amount of funds budgeted to complete it. As part of EVM, the critical key metrics is used to assess the schedule and cost performance throughout the project as in Figure 1.

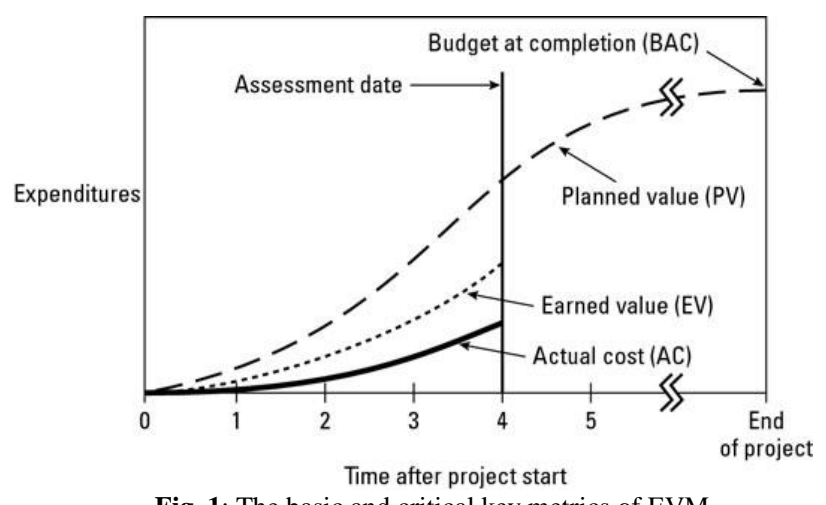

Fig. 1: The basic and critical key metrics of EVM

\subsection{Common EVM Terminology and Application}

EVM incorporated several specific mechanics such as work breakdown schedule (WBS), S - curve, and defined set of perfor- 
mance metrics. These metrics integrates project management triple constraint to monitor, control and forecast the project performances [11]. Table 1 shows common terminology used in EVM concept and Figure 2 shows the application of indicators in EVM.

Table 1: Terminology of EVM

\begin{tabular}{|c|c|c|}
\hline Name & Formula & Explanation \\
\hline $\begin{array}{l}\text { Planned } \quad \text { Value } \\
(\mathrm{PV})\end{array}$ & & $\begin{array}{l}\text { The approved budget for the work } \\
\text { scheduled to be completed by a } \\
\text { specified date }\end{array}$ \\
\hline $\begin{array}{l}\text { Earned } \quad \text { value } \\
(\mathrm{EV})\end{array}$ & & $\begin{array}{l}\text { The approved budget for the work } \\
\text { actually completed by the speci- } \\
\text { fied date }\end{array}$ \\
\hline Actual cost (AC) & & $\begin{array}{l}\text { The costs actually incurred for the } \\
\text { work completed by the specified } \\
\text { date }\end{array}$ \\
\hline $\begin{array}{l}\text { Cost Variance } \\
(\mathrm{CV})\end{array}$ & $\mathrm{EV}-\mathrm{AC}$ & $\begin{array}{l}\text { Negative means over budget } \\
\text { Positive means under budget }\end{array}$ \\
\hline $\begin{array}{l}\text { Schedule Vari- } \\
\text { ance (SV) }\end{array}$ & $E V-P V$ & $\begin{array}{l}\text { Negative means behind schedule } \\
\text { Positive means ahead schedule }\end{array}$ \\
\hline $\begin{array}{l}\text { Cost Performance } \\
\text { Index (CPI) }\end{array}$ & $\mathrm{EV} / \mathrm{AC}$ & $\begin{array}{l}\text { Determination of value returned } \\
\text { for every } 1 \$ \text { spent } \\
\text { - More than } 1 \text { indicates re- } \\
\text { sources were used in an ef- } \\
\text { ficient manner } \\
\text { - Less than } 1 \text { indicates cost } \\
\text { overruns }\end{array}$ \\
\hline $\begin{array}{l}\text { Schedule Perfor- } \\
\text { mance Index } \\
(\mathrm{SPI})\end{array}$ & $\mathrm{EV} / \mathrm{PV}$ & $\begin{array}{l}\text { Project progress compared to } \\
\text { baseline plan } \\
\text { - More than } 1 \text { indicates utilize } \\
\text { time in an efficiency man- } \\
\text { ner } \\
\text { - Less than } 1 \text { indicates sched- } \\
\text { ule behind } \\
\end{array}$ \\
\hline $\begin{array}{l}\text { Estimate at Com- } \\
\text { pletion (EAC) }\end{array}$ & $\begin{array}{l}\mathrm{EAC}=\mathrm{AC}+ \\
(\mathrm{BAC}-\mathrm{EV}) \\
\mathrm{EAC}=\mathrm{AC}+ \\
(\mathrm{BAC}-\mathrm{EV}) / \\
\mathrm{CPI}\end{array}$ & $\begin{array}{l}\text { The estimate today of the total } \\
\text { cost of the task } \\
\text { May use two approaches to calcu- } \\
\text { late the EAC: } \\
\text { Method 1: Assume that the cost } \\
\text { performance for the remainder of } \\
\text { the task will revert to what was } \\
\text { originally budgeted. } \\
\text { Method 2: Assume that the cost } \\
\text { performance for the remainder of } \\
\text { the task will be the same as what } \\
\text { it has been for the work done to } \\
\text { date. }\end{array}$ \\
\hline $\begin{array}{l}\text { Estimate to } \\
\text { Complete (ETC) }\end{array}$ & $\begin{array}{l}\mathrm{ETC}=\mathrm{EAC}- \\
\mathrm{AC} \\
\mathrm{ETC}=(\mathrm{BAC}- \\
\mathrm{EV}) / \mathrm{CPI}\end{array}$ & $\begin{array}{l}\text { Estimated cost required to com- } \\
\text { plete the remaining of the project }\end{array}$ \\
\hline $\begin{array}{l}\text { Budget At Com- } \\
\text { pletion (BAC) }\end{array}$ & & Budgeted amount for total work \\
\hline
\end{tabular}

*PV, EV, AC: basic metrics to assess the schedule and cost performance throughout the project.

* CV, SV, CPI, SPI: indicators to describe project's schedule and cost performance

*EAC, ETC, BAC: indicators to expect the total expenditures will be upon task completion

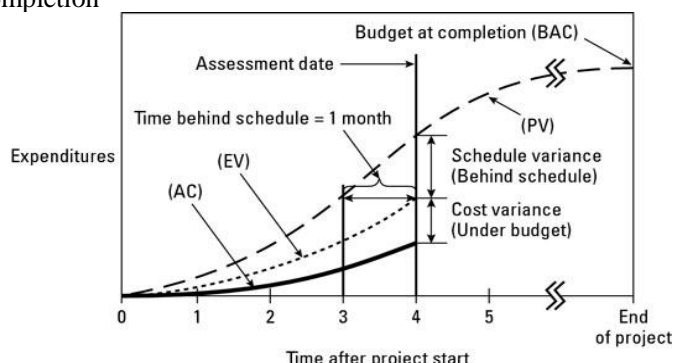

Fig. 2: The difference between planned and actual expenditures up to the date of the report is the result of both a schedule delay and cost savings.

\subsection{EVM VS. Gantt chart S-Curve}

In [13], Gantt chart been described as a classic tool in project management, which for some has become almost synonymous with project management. Gantt chart is a schedule management technique allowing project manager to calculate time of various resources required in project plan and provides recording of actual work progress of each project tasks. Generally, a list of tasks is listed in a column and horizontal time scale bar was extended to each task. This bar represents the progress of each task is drawn from the estimated starting date and ends at estimated finish date. Thus, actual work progress is recorded by updating the chart which bars will be filled with fraction accomplished work indicating percentage complete. The biggest advantage of Gantt chart is assisting in visualization that breakdown tasks based on own preferred WBS level. But, Gantt chart does not reveal the expended resources in terms of cost on tasks [13]. Thus, the interpretation of project performance may be misleading as if the project was on schedule; the maintenance of schedule based on the horizontal bar chart may be achieved under great cost overruns. An example of Gantt chart shown in Figure 3.

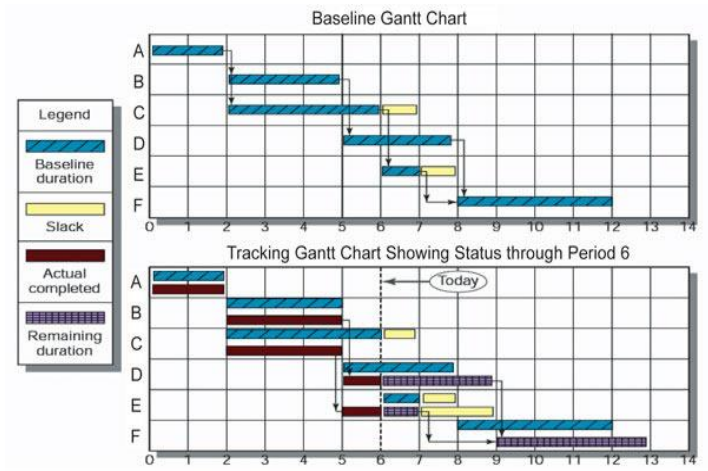

Fig. 3: A typical Gantt chart

While, $\mathrm{S}$ - curve is a graphical display cumulative progress of costs, labour hours or other quantity plotted against time [14]. It is usually achieved by summing all assigned dollar or hour values to each activity in the established Gantt chart. S-curves have become a requisite tool for project planning and control and for overall progress evaluation during the execution phase. S-curves can be used for several purposes, as a target against which the actual progress of a project can be evaluated at any point in time to monitor whether the project is on schedule [15], to forecast the likely duration of a project once the contract price and cumulative expenditure are known, to manage cash flow, current performance status, future necessary costs/duration, etc. for running projects [14-16]. The cause of S-curve drawbacks lies mainly in its lack of tying the schedule and budget to actual project progress. The Scurve simply points out deviation of cost in relation to time. It does not relation task completion to time or cost. Therefore, when a deviation is discovered it is unknown whether the project is on target so far as physical progress (whether work is being completed on, ahead or behind the anticipated time and budget). An example of S-curve shown in Figure 4.

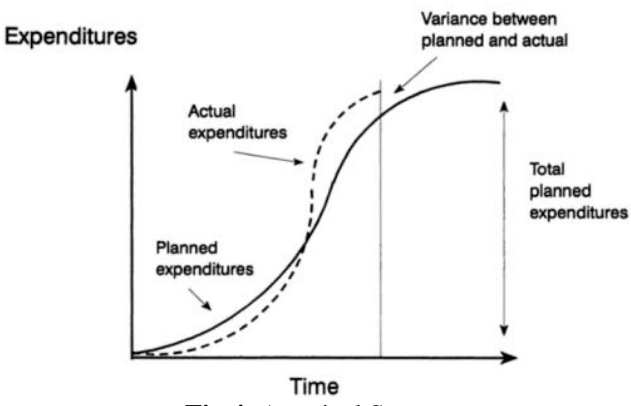

Fig.4: A typical S-curve 
The lacking of the Gantt chart is it does not reveal the expended resources in terms of cost on tasks [13]. Therefore, in order to monitor cost, bar chart was loaded with resources or budget into each task and thereafter superimposing an $S$ - curve onto the Gantt chart as in Figure 5. Superimposing S - curve on Gantt chart may look good as it ties cost from $\mathrm{S}$ - curve and schedule performance from Gantt chart together. However, the physical percentage complete field to a task view and enter values when the calculated percent completion of works would not be an accurate measure of real work performed or measured. Unlike the percentage complete field, the physical percentage completion field is independent of the total duration or actual duration values used to calculate the percentage complete field under Earned Value (EV) in EVM [7-9].

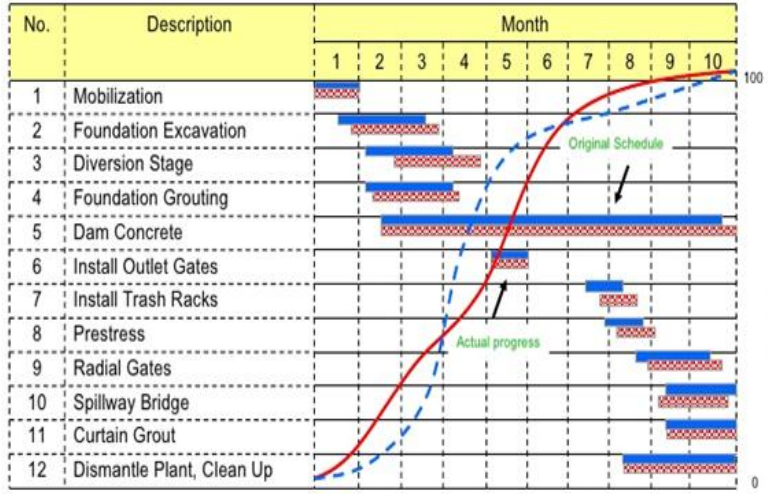

Fig.5: Superimpose $\mathrm{S}$ - curve on Gantt chart

On the other hand, in terms of financial $\mathrm{S}$ - curve in Figure 4, updating the actual cost in cost versus time curve was depending on the build - ups on Bills of Quantities with additional marginal profits and overhead that it does not reviewed the actual cost spent in the completion of project tasks [14 -16]. Besides, cost comparison for Gantt chart $\mathrm{S}$ - curve was based on the cost planned by loading budget into each task. Unlike the cumulative percentage actual cost in Gantt chart S - curve, Actual Costs (AC) in EVM measures the budget spent in view of the amount of work done so far and with the baseline cost for task, assignment or resources allocated. It compares the actual to budgeted cost assigned additionally display the resulting task expenses along with any cost incurred up to status date. Thus, looking into better cost management, EVM was developed by assessing into time and cost performance in an integrative manner [7-9]. Figure 6 will reflect an example of the cost and time performance integration of EVM concept.

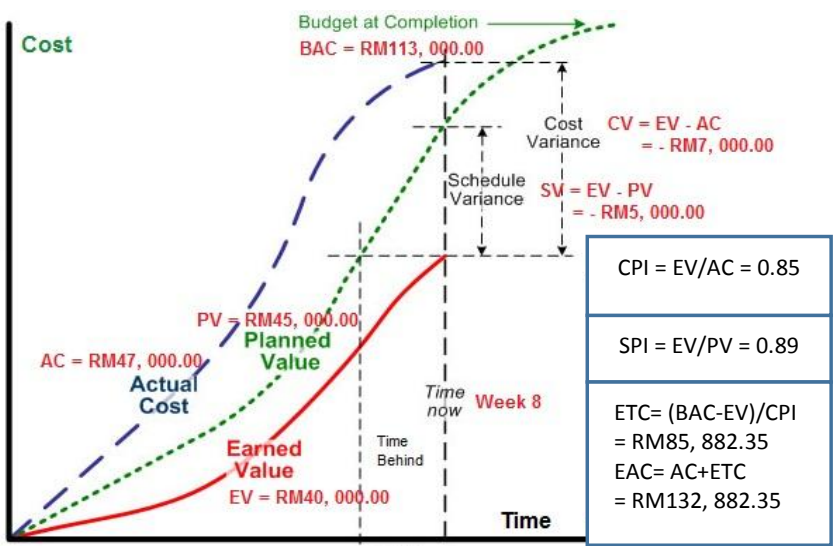

Fig. 6: EVM concept and application

Figure 6 shows the concept and application of EVM as reflected in [5] as an example. At week 8, the project indicates unhealthy conditions of schedule and cost overruns as AC lies above EV and EV curve lies below PV (negative CV and SV). In terms of CPI and
SPI, both index indicating there are $11 \%-15 \%$ pure cost and schedule overruns. Furthermore, in terms of forecasting, if negative variance, ETC can be calculated by $(\mathrm{BAC}-\mathrm{EV}) / \mathrm{CPI}=\mathrm{RM} 85$ 882.35) and $\mathrm{EAC}=\mathrm{AC}+\mathrm{ETC}=\mathrm{RM} 132,882.35)$. Hence, it shows if the project continues the same trend, the project will be RM19, 882.35 cost overruns. Thus, by this example, EVM had proven itself as an effective cost-time performance measurement tool and as an important tool required to deliver the project on time and provide forecasting.

\subsection{Challenges in Implementing EVM}

A 2010 survey by Grant Thornton LLP revealed that $28 \%$ of contractors in the survey had contracts requiring earned value management (EVM) systems. Of those, only $37 \%$ believed that EVM is a cost-effective management approach [22]. Among other challenges studied and identified in previous research as in Table 2.

Table 2: Challenges in Implementing EVM

\begin{tabular}{|c|c|c|}
\hline - & $\begin{array}{l}\text { High cost, complicated and burdensome paper } \\
\text { work } \\
\text { Poor understanding of EVM } \\
\text { Distrust and conflict between project managers, } \\
\text { project consulting and government } \\
\text { Pressures to report only good news }\end{array}$ & Kim et al.[17] \\
\hline - & $\begin{array}{l}\text { Absence of adequate project planning and docu- } \\
\text { mentation, } \\
\text { The construction schedule is compounded - re- } \\
\text { source constraints such as resource availability } \\
\text { limits and multiple calendars, } \\
\text { Activity and project delays encountered during } \\
\text { project executions, } \\
\text { NO EVM analyst or specialist within the project } \\
\text { team. }\end{array}$ & $\begin{array}{l}\text { Fleming and } \\
\text { Koppelman [18] }\end{array}$ \\
\hline- & $\begin{array}{l}\text { The parties of a contract cannot have a common } \\
\text { understanding of performance in terms of earned } \\
\text { value metrics. }\end{array}$ & $\begin{array}{l}\text { Nkiwane et al., } \\
{[19]}\end{array}$ \\
\hline & $\begin{array}{l}\text { The customer has transferred the cost risk to } \\
\text { the contractor and earned value is perceived } \\
\text { to be less useful in fixed-price contracts }\end{array}$ & $\begin{array}{l}\text { Carol and } \\
\text { Christensen } \\
{[20]}\end{array}$ \\
\hline & $\begin{array}{l}\text { The classic SPI indicators which may provide } \\
\text { false and unreliable time forecasts near the end of } \\
\text { the project. }\end{array}$ & Lipke [21] \\
\hline
\end{tabular}

\section{Research Methodology}

The research was carried out via quantitative method to investigate the implementation level of EVM in construction projects, the usage of EVM as cost management tools compared to others and the hindrances in implementing EVM from the identified focal group of contractor, project manager and quantity surveyor in Kuala Lumpur and Selangor. Questions were designed in closed ended questions and ranking scales (4=Strongly Agree, 3=Agree, 2=Disagree, $1=$ Strongly Disagree). 100 questionnaires were distributed randomly to focal groups via email. 33 feedbacks were received where 33\% from Quantity Surveying firms, 58\% from contractor firms, and $9 \%$ from project management firms and overall, $42 \%$ respondents from Selangor and $58 \%$ respondents are from Kuala Lumpur.

\section{Research Analysis \& Findings}

\subsection{Usage of EVM in Projects}

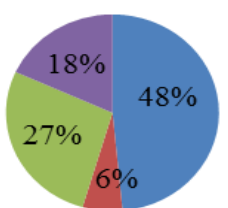

Not used

- Only few small projects

Large and critical projects

- Organization wide standard for all project control

Fig 4.1: Usage of EVM in respondent's projects 
Based on the 33 respondents mentioned above, Figure 4.1 shows $52 \%$ respondents implemented EVM in their projects. Only 6\% used in small projects; $27 \%$ respondents used for large and critical projects and $18 \%$ respondents used as organization wide standard for all kinds of project control. While, the rests of respondents, $48 \%$ do not implement EVM. Results show although quite a majority implemented it as project cost management tools; however, it still largely not using EVM as organizational standard tools but probably using other management tools.

\subsection{Preferred Tools in Project's Cost Management}

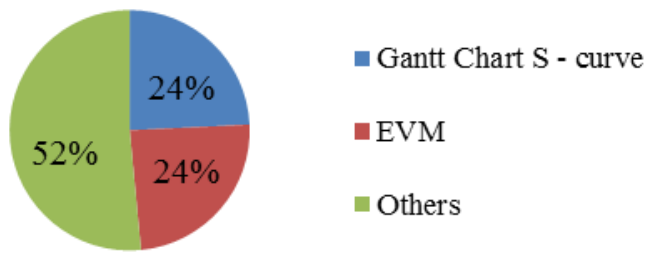

Fig 4.2: Tools preferred to be used by respondents

Figure 4.2 shows dominance of $55 \%$ respondents preferred to use "others" tools such as network diagram as project cost management tools. While, both EVM and Gantt chart S - curve are rated equally with $24 \%$ respondents. This showed that both Gantt chart $\mathrm{S}$ - curves and EVM are equally beneficial for them. This could be due to the simplicity of Gantt chart S - curve and integration of cost and time in management in EVM that brings an advantage to respondents.

\subsection{Contribution of EVM in Cost Monitoring}

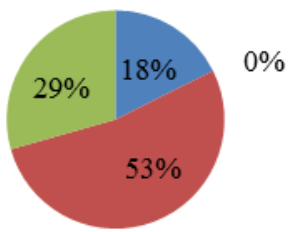

\author{
- Strongly Agree (4) \\ Agree (3) \\ Disagree (2) \\ - Strongly Disagree (1)
}

Fig 4.3: Respondent's opinion towards contribution of EVM in cost monitoring

From Figure 4.3, majority with $71 \%$ respondents agree that EVM contributes positively and as a reliable tool to project cost monitoring as EVM comparing actual performance with planned performance, analyzing variances, assessing trends to effect process improvements, evaluating possible alternatives, and recommending appropriate corrective action as needed to a project [14]. While, the minority of disagreement may be due the challenges of implementing the method caused by different factors.

\subsection{Challenges in Implementing EVM}

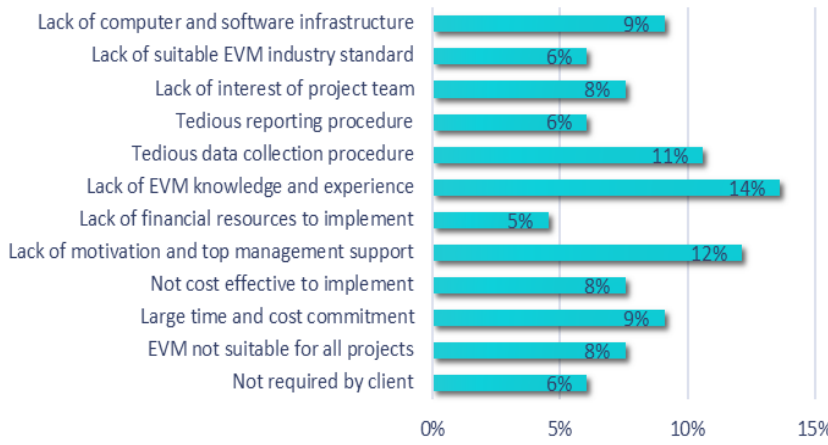

Fig. 4.4: Challenges encountered in using EVM
In Figure 4.4, the top three (3) barriers of implementing EVM is due to the lack of knowledge and experience (14\% respondents), lack of motivation and the top management support $(12 \%)$, and $11 \%$ find EVM difficult to implement is because of tedious data collection process. This findings revealed the knowledge and experience of EVM in this industry is still low probably due to 'unfamiliarity' towards this tool and not widely used as a 'standard' project management tool by the industry as in [22]. Besides, top management supports are important as well to provide encouragement in implementing EVM. Tedious data collection process is also one of the difficulties as for EVM to be effective, the data required to be collected from different parties and also various data from both cost and time as mentioned in [17-18].

\section{Conclusion}

The application of EVM as project cost management tools is still uncommon where based on the findings, the usage of EVM is only $52 \%$ which is slightly more than percentage not implementing EVM in Kuala Lumpur and Selangor. Majority of respondents agreed that EVM is an effective cost management tool and provides early warning for projects. Among the biggest challenges of EVM implementation in the industry are (1) the lacking of EVM knowledge and experience (2) the lack of motivation and top management supports and (3) tedious data collection process. In between EVM and Gantt chart s - curve as project's cost monitoring tools, both methods are equally preferable by the industry as well as other methods. In the end, the implementation of EVM as a control technique has a high impact on monitoring project schedule, controlling project cost and analysing delays.

\section{Acknowledgement}

A biggest gratitude and appreciation to my team; Lum Seon Chin and Sr Zetty Pakir Mastan to be part of this research. Also, to all parties who directly and indirectly involved and their constant encouragement in the research including the R\&D team of INTI QS department, the Head of Department, respondents and ultimately, my family members.

\section{References}

[1] Dayal, Sham (2008), Earned Value Management Using Microsoft Office Project: A Guide for Managing Any Size Project Effectively, Ft. Lauderdale, FL, USA: J. Ross Publishing Inc

[2] Hamzah Abdul-Rahman, Chen Wang, Norjumaah (2010), Project Performance Monitoring Methods used in Malaysia and Perspectives of Introducing EVA as Standard Approach, Journal of Civil Engineering and Management, Volume 17, pp. 445 - 455

[3] Howard Hunter, Richard Firzgerald, Dewey Barlow (2014), Improved cost monitoring and control through the Earned Value Management System, ActaAstronautica, Volume 93, pp. 497 - 500

[4] Jimmie W. Hinze (2008), Construction Planning and Scheduling, Third Edition, Upper Saddle River, New Jersey, Pearson Education Inc

[5] Joseph A. Griffin, PMP (2010), Residential Construction Management: Managing According to Project Lifecycle, USA, J. Ross Publishing

[6] Kym Henderson, (2007), Earned Schedule: A Breakthrough Extension to Earned Value Management, 2007 PMI Asia Pacific Global Congress Proceedings Hong Kong. Available at: http://www.earnedschedule.com/Docs/Earned\%20Schedule\%20a\% 20\%20Breakthrough\%20Extension\%20to\%20EVM\%20\%20Hende rson.pdf [Accessed 21st November 2014]

[7] Lius Felipe Candido, Luiz Fernando Mahlmann Heineck, Jose de Paula Barros Neto (2014), Critical Analysis on Earned Value Management (EVM) Technique in Building Construction, Proceedings IGLC - 22, pp. $159-170$.

[8] Mark Gershon (2013), Using Earned Value Analysis to Manage Projects, Journal of Applied Business and Economics, Volume 15 (1), pp. $11-14$ 
[9] Mohd Faris Khamidi, Waris Ali and Arazi Idrus (2011), Application of Earned Value Management System on an Infrastructure Project: A Malaysian Case Study, International Conference on Management and Service Science, Vol. 8, pp 1 - 5

[10] Nadepour, M.Mofid (2011), Improving Construction Management of an Educational Center by Applying Earned Value Technique, Procedia Engineering, Volume 14, pp. 1945 - 1952

[11] Robert A. Marshall (2007), Contribution of Earned Value Management to Project Success on Contracted Efforts, Journal of Contract Management, pp. $21-33$

[12] Zayyana Shehu, Intan Rohani Endut, Akintola Akintoye, Gary D. Holt (2013), Cost overruns in the Malaysia construction industry projects: A deeper insight, International Journal of Project Management, pp. $1-9$

[13] Joana Geraldi, Thomas Lechter, (2012) "Gantt charts revisited: A critical analysis of its roots and implications to the management of projects today", International Journal of Managing Projects in Business, Vol. 5 Issue: 4, pp.578-594, Available at: https://doi.org/10.1108/17538371211268889 [Accessed $17^{\text {th }}$ May 2018]

[14] Project Management Body of Knowledge. Project Management Institute 2013

[15] Cheng YM, Yu CH, Wang HT. Short-Interval dynamic forecasting for actual S-curve in the construction phase. J Const Eng Manag 2011;137(11):933-41

[16] Lin MC, Tseng HP, Young DL. A novel dynamic progress forecasting approach for construction projects. Experts Syst Appl 2012;39: 2247-55

[17] Kim, EunHong, Wells Jr., William G. and Duffey, Michael R. (2003). "A model for effective implementation of Earned Value Management methodology.", International Journal of Project Management 21:375-382

[18] Fleming, Quentin, Joel Koppelman (2010). "Earned Value Project Management (4th Ed.).’Project Management Institute. ISBN: 9781-935589-08-2

[19] N. H. Nkiwane, W. G. Meyer \& H. Steyn (May 2016 ) 'The use of Earned Value management for initiating directive project control decisions: a case study ', South African Journal of Industrial Engineering , 27(1), pp. 192-203

[20] Carol J. Christensen-Day (2010)."Earned Value on Fixed-Price Projects.", AACE international transactions

[21] Lipke, Walter H (2003)."Schedule is Different." The Measurable News.

[22] Ibrahim Mahdi, Ibrahim Abd-Elrashed, Ahmed Sherif Essawy, Lamisse Raed, (2018), Difficulties of Implementing Earned Value Management in Construction Sector in Egypt. International Journal of Engineering Researches and Management Studies. ISSN: 2394 $7659 . \quad$ Available at: https://www.researchgate.net/publication/323855260_DIFFICULTI ES_OF_IMPLEMENTING_EARNED_VALUE_MANAGEMENT _IN_CONSTRUCTION_SECTOR_IN_EGYPT [Accessed Dec 28 2018]. 